\title{
Lipophilic Toxin Profile in Mytilus galloprovincialis during Episodes of Diarrhetic Shellfish Poisoning (DSP) in the N.E. Adriatic Sea in 2006
}

Zivana Nincevic Gladan ${ }^{1, *}$, Ivana Ujevic ${ }^{1}$, Anna Milandri ${ }^{2}$, Ivona Marasovic ${ }^{1}$, Alfiero Ceredi ${ }^{2}$, Silvia Pigozzi ${ }^{2}$, Jasna Arapov ${ }^{1}$ and Sanda Skejic ${ }^{1}$

1 Institute of Oceanography and Fisheries, Šet. I. Meštrovića 63, 21000 Split, Croatia; E-Mails: ujevic@izor.hr (I.U.); marasovic@izor.hr (I.M.); arapov@izor.hr (J.A.); sanda@izor.hr (S.S.)

2 Fondazione Centro Ricerche Marine National Reference Laboratory on Marine Biotoxins, 47042 Cesenatico, Italy; E-Mails: anna.milandri@centroricerchemarine.it (A.M.); alfiero.ceredi@centroricerchemarine.it (A.C.); silvia.pigozzi@centroricerchemarine.it (S.P.)

* Author to whom correspondence should be addressed; E-Mail: nincevic@izor.hr; Tel.: +385 21 408015; Fax: +38521358650.

Received: 22 November 2010; in revised form: 31 December 2010 / Accepted: 18 January 2011 / Published: 21 January 2011

\begin{abstract}
Dinophysis spp. blooms and related shellfish toxicity events of diarrhetic shellfish poisoning (DSP) have been the most reported toxicity event through the Croatian National monitoring program. With the aim to characterize the DSP toxin profile in shellfish farmed in Croatia, for the first time a complete analysis of the toxin profile of Croatian mussels has been carried out using the LC-MS/MS technique. The obtained results showed okadaic acid (OA) as the main toxin contaminating Croatian mussels at that time. The maximum concentration of OA in shellfish tissue was recorded 12 days after the Dinophysis fortii bloom, thus suggesting that rapid growth of the toxin level in the shellfish occurred in the first week after the bloom while it was slower in the second week. Furthermore, the presence of only OA at concentrations which could endanger human health suggests $D$. fortii as the main organism responsible for the toxic event that occurred in Lim Bay. The presence of gymnodimine and spirolides in Croatian mussel has been detected for the first time, while the presence of yessotoxin and pectenotoxin-2 is confirmed.
\end{abstract}


Keywords: diarrhetic shellfish poisoning; okadaic acid; Dinophysis fortii; Adriatic sea

\section{Introduction}

Dinophysis spp. blooms and related shellfish toxicity events of diarrhetic shellfish poisoning (DSP) are reported worldwide due to their impact on aquaculture and human health. DSP toxins are heatstable polyether, lipophilic compounds isolated from various species of shellfish and dinoflagellates [1]. The main vector for human intoxication by phycotoxins is consumption of shellfish. The different chemical types of toxins, which are associated with the DSP syndrome, were initially classified into three groups: acidic toxins, including okadaic acid (OA) and its derivatives named dinophysistoxins (DTXs); neutral toxins consisting of polyether-lactones of the pectenotoxin group (PTXs) and sulphated compounds called yessotoxin and its derivates (YTXs). YTXs have now been categorized separately because they do not induce diarrhea [2], while a new group of toxins, called azaspiracids (AZAs), and has had to be added. Although the presence of OAs, PTXs and YTXs have been well documented in the Adriatic Sea [1,3,4,5-7] most of the studies concern the western Adriatic coast. Gymnodimines (GYMs) and spirolides are emerging lipophilic marine toxins that belong to a heterogeneous group of macrocyclic compounds called cyclic imines [8]. Since their discovery in the early 1990s, gymnodimines and spirolides have been demonstrated to have a global distribution including Adriatic Sea [9]. These toxins are well known due its "fast acting toxicity" in mouse bioassay.

The eastern part of the Adriatic Sea has been very poorly characterised so far, where research in the field of shellfish toxicity has been carried out mostly in the central area. DSP toxicity has been confirmed [10] although toxin profile data were barely detected, showing low concentrations of OA, DTX-1 and DTX-2 [11,12], which could not explain the toxicity events. In Croatian waters only PTXs were found at concentrations which could be associated with mouse bioassay positive results [12,13]. After the establishment of a national monitoring program in 2004, regular analysis of shellfish revealed that DSP toxicity events appear more often in the northern Adriatic (late summer and autumn), while their appearance in the southern part is rare [14]. With the aim of characterising the DSP toxin profile in shellfish farmed in Croatia, we analyzed positive mouse bioassay samples by LC-MS/MS.

\section{Results and Discussion}

The national monitoring program of shellfish breading areas revealed DSP toxic episodes in the northern Adriatic during the late summer and autumn period. DSP positive mouse bioassay tests were recorded at three stations: Savudrija basin (SB) and stations located at the western Istrian coast (WIC) and Lim Bay (LB) (Figure 1, Table 1). An exceptionally low survival time was recorded at the WIC station. Throughout the toxic episode only OA was found at a concentration that could be assigned to a positive mouse bioassay (Table 2). Besides toxins cited in table, YTX, PTX-2, putative 7-epi-PTX-2-SA, SPX-1 and GYM were analyzed but the levels found were $<$ LOD or $<$ LOQ. Azaspiracids (AZP), lipophilic toxins which can give positive DSP Mouse Bioassay were not analyzed in this study. Since, dinoflagellate Protoperidinium crassipes, and Azadinium spinosum which are 
identified as AZP source, have not been observed in water column at this station, we assumed that investigated shellfish were not contaminated with AZP.

Figure 1. Investigated area with sampling stations.

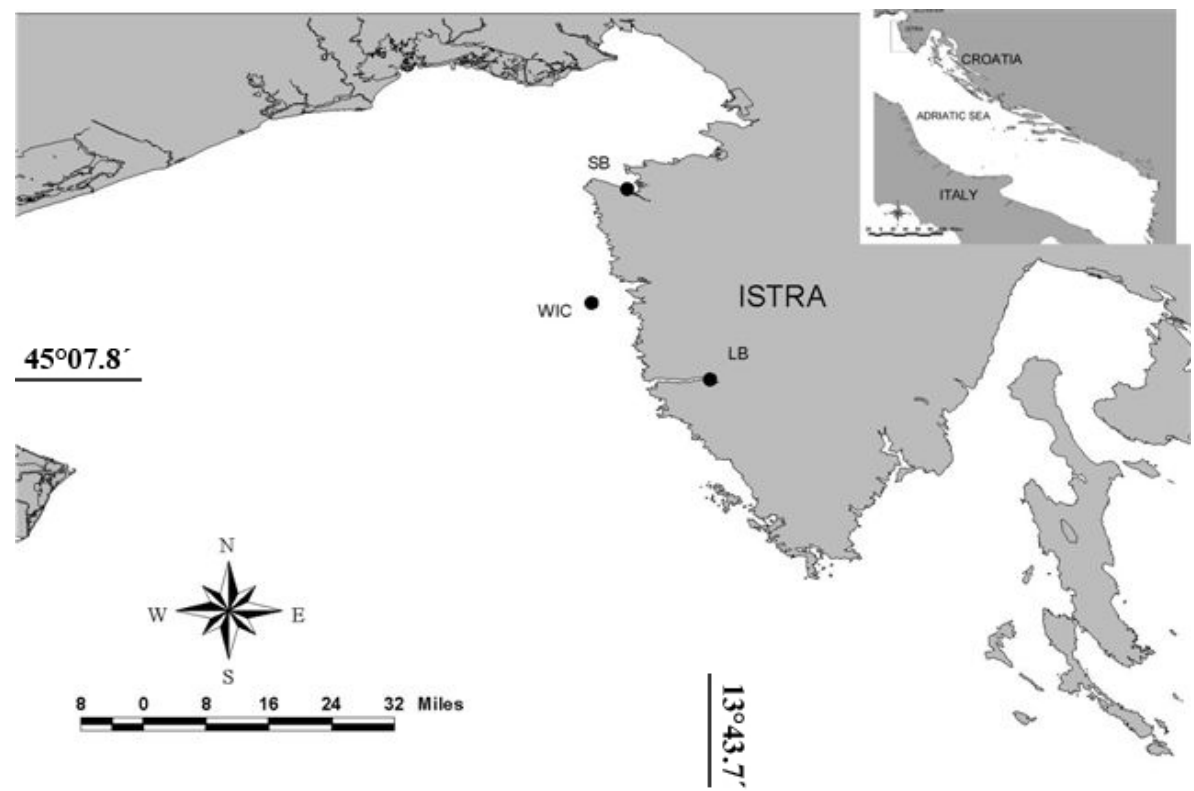

Table 1. Mortality and survival times within $24 \mathrm{~h}$ in DSP mouse bioassay.

\begin{tabular}{llll}
\hline Station & Date & Mortality & Survival times (h) \\
\hline SB & 09 October & $3 / 3$ & $3.00,3.00,4.17$ \\
SB & 16 October & $3 / 3$ & $4.00,4.00,5.00$ \\
SB & 23 October & $2 / 3$ & $3.00,3.00$ \\
WIC & 23 August & $3 / 3$ & $0.02,0.04,0.15$ \\
LB & 29 September & $3 / 3$ & $3.00,3.25,3.33$ \\
LB & 05 October & $3 / 3$ & $1.17,1.17,1.25$ \\
LB & 10 October & $3 / 3$ & $2.00,2.00,3.00$ \\
LB & 17 October & $2 / 3$ & $4.00,4.17$ \\
\hline
\end{tabular}

Table 2. Lipophilic toxins levels determined in DSP positive mussel samples.

\begin{tabular}{llllllll}
\hline Station & Date & $\begin{array}{l}\text { Free OA } \\
(\boldsymbol{\mu g} / \mathbf{k g})\end{array}$ & $\begin{array}{l}\text { OA esters } \\
(\boldsymbol{\mu g} / \mathbf{k g})\end{array}$ & $\begin{array}{l}\boldsymbol{\mu} \text { g total OA } \\
\mathbf{e q .} / \mathbf{k g}\end{array}$ & $\begin{array}{l}\text { OA esters } \\
(\boldsymbol{\%})\end{array}$ & $\begin{array}{l}\text { homoYTX } \\
(\mathbf{m g} / \mathbf{k g})\end{array}$ & $\begin{array}{l}\text { PTX-2-SA } \\
(\boldsymbol{\mu g} / \mathbf{k g})\end{array}$ \\
\hline SB & $09 / 10 / 06$ & 58 & 304 & 362 & 84 & $<\mathrm{LOQ}$ & $<\mathrm{LOQ}$ \\
SB & $16 / 10 / 06$ & 71 & 75 & 146 & 51 & $<$ LOQ & $<$ LOQ \\
SB & $23 / 10 / 06$ & 94 & 85 & 179 & 48 & 0.042 & $<\mathrm{LOQ}$ \\
WIC & $23 / 08 / 06$ & $<\mathrm{LOQ}$ & - & 78 & - & 0.130 & 15 \\
LB & $29 / 09 / 06$ & 76 & 237 & 313 & 76 & $<$ LOD & 10 \\
LB & $05 / 10 / 06$ & 418 & 669 & 1087 & 62 & $<$ LOQ & 81 \\
LB & $10 / 10 / 06$ & 307 & 915 & 1222 & 74 & $<$ LOQ & $<$ LOQ \\
LB & $17 / 10 / 06$ & 79 & 10 & 89 & 11 & $<$ LOD & $<$ LOQ \\
\hline
\end{tabular}

The highest concentration of OA was recorded at the station in Lim Bay and coincided with the shortest mouse survival time when the WIC station was excluded. The Spearman`s Rank correlation 
between OA concentrations and average mouse survival times $(\mathrm{N}=7, \mathrm{r}=-0.79, \mathrm{p}<0.05)$ confirmed $\mathrm{OA}$ as the main toxin responsible for shellfish toxicity.

An intensive bloom (1.1-3.0 $\times 10^{4}$ cell $\left.\mathrm{L}^{-1}\right)$ of Dinophysis fortii occurred in Lim Bay at the end of September and beginning of October (Figure 2). At the beginning of the bloom the toxin concentration in the mussel exceeded regulatory toxin limits and maximum concentrations were reached after two weeks. In the first week toxin level growth was rapid and increased 3.5 times (Figure 2). In the second week after the bloom, the toxin level rise was much slower. Seven days after the $D$. fortii bloom terminated, mussel toxin levels fell to $7 \%$.

Figure 2. Abundances of $D$. fortii in water samples and concentrations of okadaic acid (OA) in shellfish samples obtained from Lim Bay.

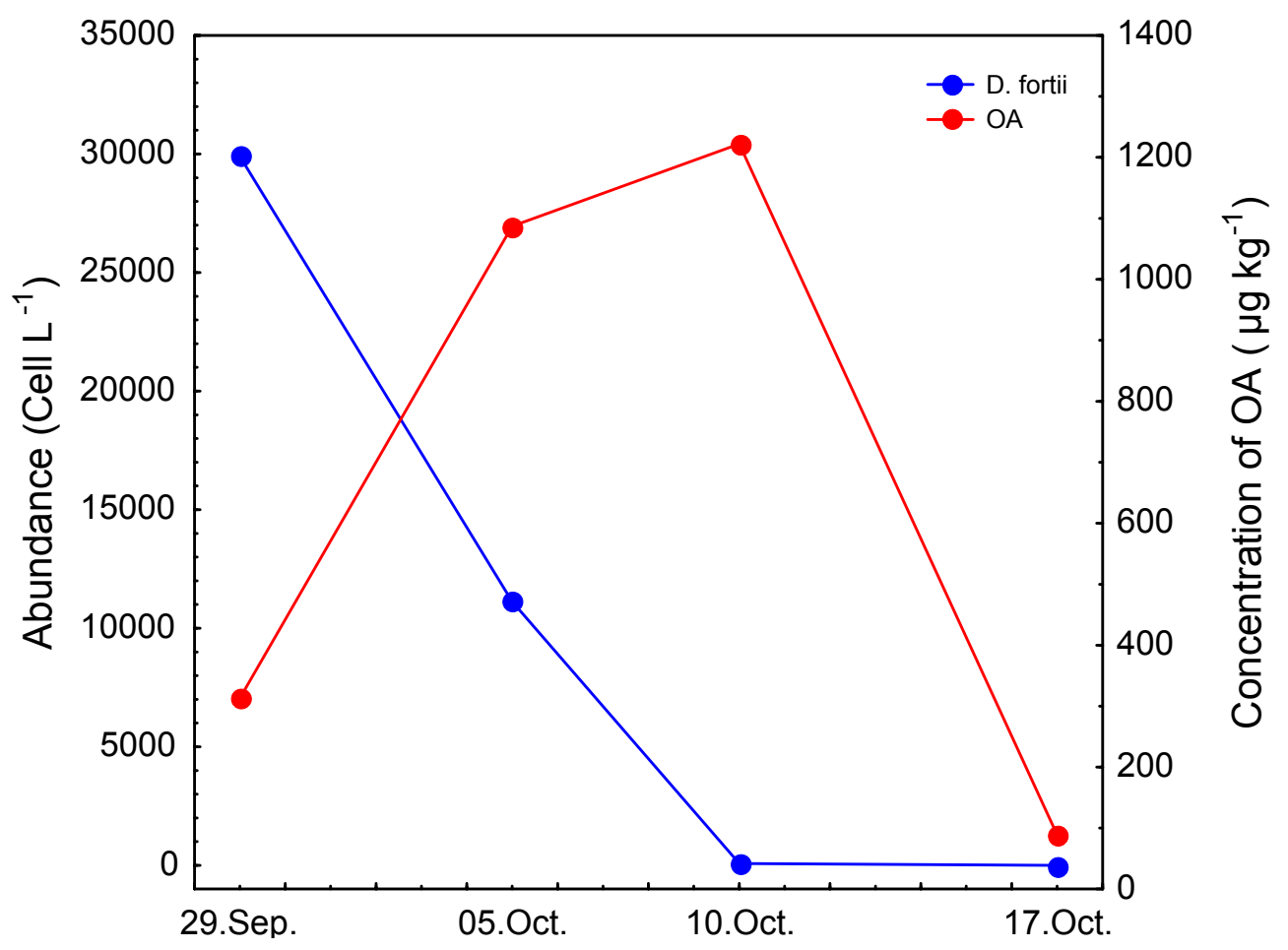

Bloom of $D$. fortii accompanied by shellfish toxicity recurred in Lim Bay in the autumn of years 2007, 2008 and 2010 (unpublished data). The relation of $D$. fortii to OA shellfish contamination had been previously reported [1,15]. Among Dinophysis species, D. acuminata is the most studied [16-18] and the most reported species that produces OA [19-23], which is probably due to its more intensive and common occurrence.

Comparison of OA concentrations in mussels determined in this study with these from Thermaikos Gulf during D. acuminata bloom, which occurs at a similar intensity [22] as D. fortii in Lim Bay, revealed two and three times higher OA concentrations in mussels from Thermaikos Bay than those mussels analyzed in this study. These differences can result from species specific toxin profile, different cellular toxin content or/and the ratio of toxigenic cells to the total particulate matter filtred by the shellfish. Cellular toxin content is variable and depends on many physiological and environmental factors as growth phase, physiological stress (sharp changes in salinity or nutrient deficiency), cellular division, assimilation of amino acids [24,25]. Several authors have postulated that 
the DSP toxins in Dinophysis cells would not be due to synthesis but rather to the ingestion of picophytoplankton which produces the toxins [26,27]. This might explain the great differences in toxin content per cell in Dinophysis. Mixotrophic feeding behavior of Dinophysis spp. has been pointed as possible explanation of the high variability of toxin content per cell. Relationship between mussel toxin levels and ratio of toxigenic cells to the total particulate matter filtered by the shellfish are based on quantity and quality of food available to the bivalves. In waters low in particulate organic matter, filter feeders need to filter larger volumes to accomplish its nutritional needs. Dahl and Johannessen [28] recommended the use of the ratio between Dinophysis acuta and the chlorophyll content as a better index to predict DSP events associated with this species.

The maximum concentration of OA in shellfish tissue was recorded 12 days after the $D$. fortii bloom, thus suggesting that rapid growth of the toxin level in the shellfish occurred in the first week after the bloom while it was slower in the second week. Morano et al. [19] recorded a similar result in the Ria de Vigo, Spain where the maximum concentration in shellfish was recorded 16 days after a $D$. acuminata bloom. Seven days after maximal concentrations in shellfish were achieved; levels fell to $7 \%$. This significant loss of OA from shellfish have been accompanied by decrease of toxic cell in water column and appears 7 days after $D$. fortii abundances fall down from $1,1 \times 10^{4}$ to 80 cells $\mathrm{L}^{-1}$.

Different depuration rate has been reported in various geographic areas. Svensson [29] reported a depuration rate with an average of $50 \%$ reduction after 32 days, which she attributed to the low temperature since the experiment was performed in the Swedish coastal water in November. Slow depuration rate with a semidepuration time of 35-45 days for toxin elimination has been reported by Duinker et al. [30] for mussels from Norway. Depuration rate of 50\% reduction after 1.5 months was observed Lindahl and Hageltorn [31] in Swedish waters. Faster depuration rates are observed in the southern areas in comparison to Nordic contries. In Spanish waters, Fernandez et al. [32] observed 50\% reduction in 11-12 days, Blanco et al. [33] and Morano et al. [19] reported 50\% reduction in 7-8 days. In French waters, Marcaillou-Le Baut et al. [34] reported 50\% reduction of DST in 12 days. Poletti et al. [35] recorded semi-depuration time of 3.3 days in Adriatic Sea during sea water temperature above $20^{\circ} \mathrm{C}$. These differences in depuration rates between Nordic and Mediterranean countries could be attributed to temperature diversity, but at least partly it could be a result of different mussels species used. It has been assumed that depuration is faster in higher temperatures due to a generaly higher metabolic activity [36], however, the degree to which temperature affects the uptake and release of toxins is still unknown. The attempts made to obtain precise estimates of temperature effects did not result in any clear conclusion [29,31,33,37] on what could be attributed to the stress effects caused by abrupt temperature changes. The consistent differences in depuration rates have been seen between different seasons [38], with faster depuration rates in summer compared to autumn, an observation that could be associated with temperature influence. Studies on the effect of food quality and availability on depuration rate provide conflicting results. Some studies suggest that the quantity or quality of the food sources affect the depuration rates [34,33], while other studies in field and laboratory suggest that neither food levels, salinity or temperature affect the depuration rates $[29,37]$.

The relationship between toxic phytoplankton and toxin occurrence was not recorded at stations SB and WIC and is probably a consequence of the phytoplankton sampling method. At station SB Dinophysis rotundata $\left(80\right.$ cells $\mathrm{L}^{-1}$ ) were recorded in September. At station WIC in July D. sacculus and Protoperidinium crassipes were recorded in abundance of 80 cells $\mathrm{L}^{-1}$. In the present study 
seawater was sampled with a sampling tube where it is possible that big cells were avoided, especially if they were not present in high concentrations unlike at the LB station. Net sampling is more adequate for the detection of low abundance species in seawater for toxic phytoplankton controls [14,39].

Besides OA, low levels $\left(0.13 \mathrm{mg} \mathrm{kg}^{-1}\right)$ of YTX analogs and PTX-2 in some samples were detected (Table 2). The presence of YTX, previously has been reported [40,41]. Although YTX shows high lethality when it is intraperitoneally injected in mice [42] its concentration recorded at the WIC station was too low, in relation to the rapidity of mouse death (Table 1), for it to be attributed to the positive mouse bioassay. These rapid deaths of mice usually were assigned to spirolides and gymnodimine, which were not detected in this sample. It is possible that there were false positive results which may have occurred if the free fatty acids were present $[43,44]$ or acetone and diethyl ether remained in the shellfish extract [45].

Gymnodimine and spirolides, which are known as "fast-acting toxins", were recorded in Croatian mussels for the first time, but at concentrations below the limit of quantification $(<12 \mu \mathrm{g} / \mathrm{kg})$. Gymnodimine was detected at station SB, while SPX-1 was detected at station LB. Spirolides found at the LB station could be assigned to the presence of Alexandrium ostenfeldii, which is the causative organism of spirolide toxins [46,47]. A. ostenfeldii was recorded at the LB station seven days prior to the day when spirolide in mussels was detected at concentrations of $6.7 \times 10^{3}$ cell $\mathrm{L}^{-1}$. Its concentration fall to 400 cell $\mathrm{L}^{-1}$ seven days after spirolides were detected. Gymnodimine presence at the LB station could be related to high abundance of Gymnodinium spp. $\left(7.1 \times 10^{5}\right.$ cells $\left.\mathrm{L}^{-1}\right)$, which had occured twelve days previously. A wide distribution of Gymnodimine has been reported around the New Zealand coastline [48] and has recently been identified in shellfish from Tunisia [49].

The present study confirmed the continuing presence of PTX in mussels from the Adriatic Sea. Pavela-Vrančić et al. [12,50] reported for the first time the presence of the PTX derivative, 7-epipectenotoxin-2-seco acid in mussels from the middle Adriatic. This study gives the first evidence of PTX presence in the northern Adriatic and its existence could be related to an intensive bloom of $D$. fortii which is known as the causative organism of PTX [1]. The concentration of PTX was very low (Table 2) indicating that $D$. fortii cells mainly were responsible for OA occurrence in mussels in this instance.

\section{Experimental}

\subsection{Sampling activities}

Mussel (Mytilus galloprovincialis) and seawater samples were collected weekly from August to October 2006 at shellfish farms located in the northeastern (NE) Adriatic (Figure 1). Each mussel sample was split in two sub-samples for mouse bioassay (MBA) and LC-MS/MS analysis. Hepatopancreas was used as the test portion for MBA, while the whole flesh tissue was used for the chemical analysis of lipophilic toxins. Integrated seawater samples were collected using a PVC tube sampler for phytoplankton analysis. 


\subsection{Mouse bioassay}

Analysis of DSP toxicity by mouse bioassay was performed following the method developed by Yasumoto and collaborators [51]. The method included extraction of $20 \mathrm{~g}$ mussel hepatopancreas with acetone. The extract was then evaporated and the residue was partitioned between diethyl ether and water. The organic fraction was evaporated to dryness and the final residue was dissolved in $4 \mathrm{~mL} 1 \%$ Tween 60. Aliquots $(1 \mathrm{~mL})$ of this solution were intraperitoneally injected into three mice $(18-20 \mathrm{~g})$. Observation time was 24 hours but the test was regarded as positive if at least two out of three mice died within five hours [52,53].

\subsection{Liquid chromatography-mass spectrometry}

Further investigations on those samples that gave positive results by the MBA for lipophilic toxins were carried out by liquid chromatography tandem mass spectrometry. Homogenised mussel tissues were extracted once with methanol $90 \%$ (sample to solvent ratio $=10$ ). Extracts were then washed with n-hexane and filtered before injection into LC. LC-MS/MS analyses were performed using a 1,200 L triple quadrupole mass spectrometer equipped with an electrospray ionisation source (Varian Inc., Walnut Creek, CA, USA).

Methanol of HPLC grade was purchased from VWR (Milan, Italy). Water was distilled and passed through a MilliQ water purification system (Millipore Ltd., Bedford, MA, USA). Formic acid (reagent grade $\geq 95 \%$ ) was purchased from Sigma-Aldrich (Steinheim, Germany), while ammonium hydrate for analysis was purchased from Carlo Erba (Milan, Italy). Certified reference materials for OA, DTX-1, PTX-2, YTX, GYM and SPX-1 were purchased from CNRC (Halifax, NS, Canada) and were used for correct identification and quantification of toxins in mussel samples. Analogues of the previously mentioned toxins were identified by direct comparison with contaminated samples of known composition.

Chromatographic separation was performed using a $5 \mu \mathrm{m}$ SunFire C18, $150 \times 2.1 \mathrm{~mm}$ column (Waters Corporation, Milford, MA, USA) kept at $30^{\circ} \mathrm{C}$. Mobile phase A consisted of methanol-water $(13: 87, \mathrm{v} / \mathrm{v})$ containing $50 \mathrm{mM}$ formic acid and $4 \mathrm{mM}$ ammonium hydrate. Mobile phase $\mathrm{B}$ consisted of methanol-water $(90: 10, \mathrm{v} / \mathrm{v})$ containing containing $4.5 \mathrm{mM}$ formic acid and $5.4 \mathrm{mM}$ ammonium hydrate. Flow rate was $200 \mu \mathrm{L} \mathrm{m^{-1 }}$. A step gradient elution was used: $0 \%$ B for 3 min, $0-97 \%$ B in $4 \mathrm{~min}, 97 \%$ B for $15 \mathrm{~min}$. Re-equilibration time at the initial conditions was $8 \mathrm{~min}$. Multiple reaction monitoring (MRM) experiments were carried out in positive/negative switching ion mode in order to investigate the presence of the following toxins: GYM (m/z $508>490 \mathrm{ES}+)$; SPX-1 ( $\mathrm{m} / \mathrm{z} 692>444$; m/z $692>164$ ES+); OA and DTX-2 (m/z $803>255$ ES-); DTX-1 (m/z $817>255$ ES-); PTX-2 (m/z $876>823$ ES +$)$; PTX-1 (m/z $892>839$ ES+); PTX-2-SA and putative 7-epi-PTX-2-SA $(\mathrm{m} / \mathrm{z} 894>823$ ES +$)$; PTX-6 (m/z $906>853$ ES +$)$; YTX (m/z 1,141 > 1,061 ES-); homoYTX $(\mathrm{m} / \mathrm{z} 1,155>1,075$ ES-); 45-OHYTX ( $\mathrm{m} / \mathrm{z} 1,157>1,077$ ES-); 45-OHhomoYTX $(m / z$ 1,171 > 1,091 ES-).

Detection limits were calculated based on a signal/noise $(\mathrm{S} / \mathrm{N})$ ratio of 3. LODs: OA $7 \mu \mathrm{g} / \mathrm{kg}$; DTX$17 \mu \mathrm{g} / \mathrm{kg}$; DTX-2 $7 \mu \mathrm{g} / \mathrm{kg}$; YTX $0.010 \mathrm{mg} / \mathrm{kg}$; homoYTX $0.010 \mathrm{mg} / \mathrm{kg} ; 45-\mathrm{OH}$ YTX $0.010 \mathrm{mg} / \mathrm{kg}$; 
45-OH homoYTX $0.010 \mathrm{mg} / \mathrm{kg}$; PTX-2 $4 \mu \mathrm{g} / \mathrm{kg}$; PTX-2-SA $4 \mu \mathrm{g} / \mathrm{kg}$; putative 7-epi-PTX-2-SA $4 \mu \mathrm{g} / \mathrm{kg}$; SPX-1 $4 \mu \mathrm{g} / \mathrm{kg}$; GYM $4 \mu \mathrm{g} / \mathrm{kg}$.

Quantification limits were calculated based on a signal/noise $(\mathrm{S} / \mathrm{N})$ ratio of 10 . LOQs: OA $20 \mu \mathrm{g} / \mathrm{kg}$; DTX-1 $20 \mu \mathrm{g} / \mathrm{kg}$; DTX-2 $20 \mu \mathrm{g} / \mathrm{kg}$; YTX $0.030 \mathrm{mg} / \mathrm{kg}$; homoYTX $0.030 \mathrm{mg} / \mathrm{kg}$; 45-OH YTX $0.030 \mathrm{mg} / \mathrm{kg}$; 45-OH homoYTX $0.030 \mathrm{mg} / \mathrm{kg}$; PTX-2 $12 \mu \mathrm{g} / \mathrm{kg}$; PTX-2-SA $12 \mu \mathrm{g} / \mathrm{kg}$; putative 7epi-PTX-2-SA $12 \mu \mathrm{g} / \mathrm{kg}$; SPX-1 $12 \mu \mathrm{g} / \mathrm{kg}$; GYM $12 \mu \mathrm{g} / \mathrm{kg}$.

\subsection{Alkaline hydrolysis}

The hydrolysis procedure, as proposed by Mountfort et al. [54] with slight modifications, was carried out by adding $2.5 \mathrm{M} \mathrm{NaOH}(100 \%$ aqueous, $125 \mu \mathrm{L})$ to $1 \mathrm{~mL}$ of sample crude extract. The mixture was kept at $76{ }^{\circ} \mathrm{C}$ for $40 \mathrm{~min}$. After cooling to room temperature, the extract was acidified with $2.5 \mathrm{M} \mathrm{HCl}(125 \mu \mathrm{L})$. The $\mathrm{pH}$ values of each extract after hydrolysis and addition of $\mathrm{HCl}$ ranged between 5.0 and 7.0, depending on the matrix.

\subsection{Phytoplankton analysis}

An aliquot of seawater $(250 \mathrm{~mL})$ was preserved in glutaraldehyde solution (final concentration $0.5 \%$ ). Dinophysis spp. cells as well as other phytoplankton species were identified and counted using an inverted microscope (Olympus IX50) according to Utermöhl [55]. Toxic species were counted on the whole chamber's bottom. Results were expressed as cells $\mathrm{L}^{-1}$.

\section{Conclusions}

For the first time a complete analysis of the toxin profile of Croatian mussels has been carried out using the LC-MS/MS technique, which is characterized by high sensitivity and specificity. The obtained results showed $\mathrm{OA}$ as the main toxin contaminating Croatian mussels at that time. High concentrations of OA in mussels during the DSP toxic episode showed that a positive mouse bioassay could be fully attributed to the OA. Furthermore, the presence of only OA at concentrations which could endanger human health suggests $D$. fortii as the main organism responsible for the toxic event that occurred in Lim Bay. The presence of gymnodimine and spirolides in Croatian mussel has been detected for the first time while the presence of yessotoxin and pectenotoxin-2 is confirmed.

\section{Acknowledgements}

This research was supported by funding from the Croatian Ministry of Science, Education and Sports through grants 001-0010501-0848 and 001-0013077-0845.

\section{References and Notes}

1. Draisci, R.; Lucentini, L.; Giannetti, L.; Boria, P.; Poletti, R. First report of pectenotoxin-2 (PTX2) in algae (Dinophysis fortii) related to seafood poisoning in Europe. Toxicon 1996, 34, 923-935.

2. Aune, T.; Sorby, R.; Yasumoto, T.; Ramstad, H.; Landsverk, T. Comparison of oral and intraperitoneal toxicity of yessotoxin towards mice. Toxicon 2002, 40, 77-82. 
3. Fattorusso, E.; Ciminiello, P.; Costantino, V.; Magno, S.; Mangoni, A.; Milandri, A.; Poletti, R.; Pompei, M.; Viviani, R. Okadaic acid in mussels of Adriatic Sea. Mar. Pollut. Bull. 1992, 24, 234-237.

4. Draisci, R.; Lucentini, L.; Giannetti, L.; Boria, P.; Stacchini, A. Detection of diarrhoetic shellfish toxins in mussels from Italy by ionspray liquid chromatography-mass spectrometry. Toxicon 1995, 33, 1591-1603.

5. Ciminiello, P.; Fattorusso, E.; Forino, M.; Magno, S.; Poletti, R.; Satake, M.; Viviani R.; Yasumoto, T. Yessotoxin in mussels of the Northern Adriatic Sea. Toxicon 1997, 35, 177-183.

6. Draisci, R.; Ferretti, E.; Palleschi, L.; Marchiafava C.; Poletti, R.; Milandri, A.; Ceredi, A.; Pompei, M. High levels of yessotoxin in mussels and presence of yessotoxin and homoyessotoxin in dinoflagellates of the Adriatic Sea. Toxicon 1999, 37, 1187-1193.

7. Ciminiello, P.; Dell'Aversano, C.; Fattorusso, E.; Forino, M.; Tartaglione, L.; Boschetti, L.; Rubini, S.; Cangini, M.; Pigozzi, S.; Poletti, R. Complex toxin profile of Mytilus galloprovincialis from the Adriatic sea revealed by LC-MS. Toxicon 2010, 55, 280-288.

8. Molgó, J.; Girard, E.; Benoit, E. Cyclic Imines: An Insight into this Emerging Group of Bioactive Marine Toxins. In Phycotoxins: Chemistry and Biochemistry; Botana, L.M., Ed.; Blackwell Publishing: Ames, IA, USA, 2007; 319-335.

9. Ciminiello, P.; Dell'Aversano, C.; Fattorusso, E.; Magno, S.; Tartaglione, L.; Cangini, M.; Pompei, M.; Guerrini, F.; Boni, L.; Pistocchi, R. Toxin profile of Alexandrium ostenfeldii (Dinophyceae) from the Northern Adriatic Sea revealed by liquid chromatography-mass spectrometry. Toxicon 2006, 47, 597-604.

10. Marasović, I.; Ninčević, Ž.; Pavela-Vrančić, M.; Orhanović, S. A Survey of Shellfish Toxicity in the Central Adriatic Sea. J. Mar. Biol. Ass. UK 1998, 78, 1-10.

11. Orhanović, S.; Ninčević, Ž.; Marasović, I.; Pavela-Vrančić. M. Phytoplankton Toxins in the Central Adriatic Sea. Croat. Chem. Acta 1996, 69, 291-303.

12. Pavela-Vrančić, M.; Meštrović, V.; Marasović, I.; Gillman, M.; Furey, A.; James, K. K. The occurrence of 7-epi-pectenotoxin-2 seco acid in the coastal waters of the central Adriatic (Kaštela Bay). Toxicon 2001, 39, 771-779.

13. Pavela-Vrančić, M.; Meštrović, V.; Marasović, I.; Gillman, M.; Furey, A.; James, K. K. DSP toxin profile in the coastal waters of the central Adriatic Sea. Toxicon 2002, 40, 1601-1607.

14. Ninčević Gladan, Ž.; Skejić, S.; Bužančić, M.; Marasović, I.; Arapov, J.; Ujević, I.; Bojanić, N.; Grbec, B.; Kušpilić, G.; Vidjak, O. Seasonal variability in Dinophysis spp. abundances and DSP outbreaks along the eastern Adriatic coast. Bot. Mar. 2008, 51, 449-463

15. Vale, P.; Sampayo, M.A.M. Seasonality of diarrhetic shellfish poisoning at a coastal lagoon in Portugal: rainfull patterns and folk wisdom. Toxicon 2003, 41, 187-197.

16. Lassus, P.; Herbland, A.; Lebaut, C. Dinophysis blooms and toxic effects along French coast. World Aquacult. 1991, 22, 49-54.

17. Klöpper, S.; Scharek, R.; Gerdts, G. Diarrhetic shellfish toxicity in relation to abundance of Dinophysis spp. in the German Bight near Helgoland. Mar. Ecol. Prog. Ser. 2003, 259, 93-102.

18. Koukaras, K.; Nikolaidis, G. Dinophysis blooms in Greek coastal waters (Thermaikos Gulf, NW Aegean Sea). J. Plankton Res. 2004, 26, 445-457. 
19. Morano, A.; Arévalo, F.; Fernández, M.L.; Maneiro, J.; Pazos, Y.; Salgado, C.; Blanco, J.Accumulation and transformation of DSP toxins in mussels Mytilus galloprovincialis during a toxic episode caused by Dinophysis acuminata. Aquat. Toxicol. 2003, 62, 269-280.

20. Ciminiello, P.; Dell'Aversano, C.; Fattorusso, E.; Forino, M.; Magno, S.; Santelia, F.; Tsoukatou, M. Investigation of the toxin profile of Greek mussels Mytilus galloprovincialis by liquid chromatography—mass spectrometry. Toxicon 2006, 47, 174-181.

21. Lindahl, O.; Lundve, B.; Johansen, M. Toxicity of Dinophysis spp. in relation to population density and environmental conditions on the Swedish west coast. Harmful Algae 2007, 6, 218-231.

22. Reizopoulou, S.; Strogyloudi, E.; Giannakourou, A.; Pagou, K.; Hatzianestis, I.; Pyrgaki, C. Granéli, E. Okadaic acid accumulation in macrofilter feeders subjected to natural blooms of Dinophysis acuminata. Harmful Algae 2008, 7, 228-234.

23. Rossignoli, A.E.; Blanco, J. Subcellular distribution of okadaic acid in the digestive gland of Mytilus galloprovincialis: First evidences of lipoprotein binding to okadaic acid. Toxicon 2010, 55, 221-226.

24. Rausch de Traubenberg, C.; Morlaix, M. Evidence of okadaic acid release into intracellular medium in cultures of Prorocentrum lima (Ehrenberg) Dodge. In Harmful Marine Algal Blooms; Lassus, P., Arzul, G., Erard, E., Gentien, P., Marcaillou, C., Eds.; Lavoisier, Intercept Ltd: Paris, France, 1995; pp. 493-498.

25. Johansson, N.; Graneli, E.; Yasumoto, T.; Carlsson, P.;Legrand, C. Toxin production by Dinophysis acuminata and $D$. acuta cells grown under nutrient sufficient and deficient conditions. In Harmful and Toxic Algal Blooms; Yasumoto, T., Oshima, Y., Fukuyo, Y., Eds.; IOC of UNESCO: Paris, France, 1996; pp. 277-280.

26. Nishitani, G.; Sugioka, H.; Imai, I. Seasonal distribution of species of the toxic dinoflagellate genus Dinophysis in Maiziru Bay (Japan), with comments on their autofluorescence and attachment of picophytoplankton. Harmful Algae 2002, 1, 253-264.

27. Imai, I.; Sugioka, H.; Nishitani, G.; Mitsuya, T.; Hamano, Y. Monitoring of DSP toxins in smallsized plankton fraction of seawater collected in Mutsu Bay, Japan, by ELISA method: relation with toxin contamination of scallop. Mar. Poll. Bull. 2003, 47, 114-117.

28. Dahl, E.; Johannessen, T. Relationship between occurrence of Dinophysis species and shellfish toxicity. Phycologia 2001, 40, 223-227.

29. Svensson, S. Depuration of okadaic acid (Diarrhetic Shellfish Toxin) in mussels, Mytilus edulis (Linnaeus), feeding on different quantities of nontoxic algae. Aquaculture 2003, 218, 277-291.

30. Duinker, A.; Bergslien, M.; Strand, Ø.; Olseng, C.D.; Svardal, A. The effect of size and age on depuration rates of diarrhetic shellfish toxins (DST) in mussels (Mytilus edulis L.), Harmful Algae 2007, 6, 288-300.

31. Lindahl, O.; Hageltorn, M. Detoxification experiments of DSP in blue mussels. In Proceedings of the 4th Nordic Veterinary Congress, Stockholm, Sweden, 1986; pp. 463-466.

32. Fernández, M.L.; Míguez, A.; Morono, A.; Cacho, E.; Martínez, A.; Blanco, J. Detoxification of low polarity toxins (DTX-3) from mussels Mytilus galloprovincialis in Spain. In Harmful Algae; Reguera, B., Blanco, J., Fernández, M.L., Wyatt, T., Eds.; Xunta de Galicia and 
Intergovernmental Oceanographic Commission of UNESCO: Santiago de Compostela, Spain, 1998; pp. 449-452.

33. Blanco, J.; Fernández, M.L.; Míguez, A.; Morono, A. Okadaic acid depuration in the mussel Mytilus galloprovincialis: One- and two-compartment models and the effect of environmental conditions. Mar. Ecol. Prog. Ser. 1999, 176, 153-163.

34. Marcaillou-Le Baut, C.; Bardin, B.; Bardouil, M.; Bohec, M.; Le Dean, L.; Masselin, P.; Truquet, P. Toxic Phytoplankton Blooms in the Sea. In DSP Depuration Rates of Mussels Reared in a Laboratory and an Aquaculture Pond; Smayda, T.J., Shimizu, Y., Eds.; Elsevier: Amsterdam, The Netherlands, 1993; pp. 531-535.

35. Poletti, R.; Viviani, R.; Casadei, C.; Lucentini, L.; Funari, E.; Draisci, R. Decontamination dynamics of mussels naturally contaminated with diarrhetic toxins relocated to a basin of the Adriatic sea. In Harmful and Toxic Algal Blooms; Yasumoto, T., Oshima, Y., Fukuyo, Y., Eds.; Intergovernmental Oceanographic Commission of UNESCO: Paris, France, 1996; pp. 429-432.

36. Shumway, S.E.; van Egmond, H.P.; Hurst, J.W.; Bean, L.L. Manual on Harmful Marine Microalgae. In Management of Shellfish Resources; Hallegraeff, G.M., Anderson, D.M., Cembella, A., Eds.; UNESCO: Paris, France, 1995; pp. 433-462.

37. Svensson, S.; Förlin, L. Analysis of the importance of lipid breakdown for elimination of okadaic acid (diarrhetic shellfish toxin) in mussels, Mytilus edulis: results from a field study and a laboratory experiment. Aquat. Toxicol. 2004, 66, 405-418.

38. Svensson, S. Effects, dynamics and management of okadaic acid in blue mussels, Mytilus eduls. PhD Thesis, Göteborg University, 2003, p. 50.

39. Sidari, L.; Nichetto, P.; Cok, S.; Sosa, S.; Tubaro, A.; Honsell, G.; Della Loggia, R. Phytoplankton detection and DSP toxicity: methodological considerations. J. Appl. Phycol. 1995, 7, 163-166.

40. Ninčević-Gladan, Ž.; Marasović, I.; Skejić, S.; Bužančić, M.; Ujević, I.; Arapov, J. Harmful algal bloom monitoring program at the shell-fish breading areas through the eastern Adriatic coast (an overview). In Book of Proceedings $2^{\text {nd }}$ Congress of the Alps-Adria Working Community on Maritime, Undersea, and Hyperbaric Medicine, Zadar, Petri, N., Ed.; Naval Medical Institute of the Croatian Navy: Split, Croatia, 18-21 October 2006; pp. 145-156.

41. Ninčević Gladan, Ž.; Ujević, I.; Milandri, A.; Marasović, I.; Ceredi, A.; Pigozzi, S.; Arapov, J.; Skejić, S.; Orhanović, S.; Isajlović, I. Is Yessotoxin the Main Phycotoxin in Croatian Waters? Mari. Drugs 2010, 8, 460-470.

42. Ogino, H.; Kumagai, M.; Yasumoto, T. Toxicologic evaluation of yessotoxin. Nat. Toxins 1997, 5, 255-259.

43. Yasumoto, T.; Oshima, Y.; Yamaguchi, M. Occurrence of a new type of shellfish poisoning in the Tohoku district. Bull. Jpn. Soc. Sci. Fish. 1978, 44, 1249-1255.

44. Lee, J.S.; Yanagi, T.; Kenma, R.; Yasumoto, T. Fluorometric determination of diarrhetic shellfish toxins by high pressure liquid chromatography. Agric. Biol. Chem. 1987, 51, 877-881.

45. Scotter, M.J.; Roberts, D.P.T. Development and validation of a rapid headspace gas chromatography-mass spectrometry method for the determination of diethyl ether and acetone residues in Tween extracts of shellfish intended for mouse bioassay for diarrhoetic toxins. $J$. Chromatogr. A 2007, 1157, 386-390. 
46. Cembella, A.D.; Lewis, N.I.; Quilliam, M.A. Spirolide composition of micro-extracted pooled cells isolated from natural plankton assemblages and from cultures of the dinoflagellate Alexandrium ostenfeldii. Nat. Toxins 1999, 7, 197-206.

47. Cembella, A.D.; Lewis, N.I.; Quilliam, M.A. The marine dinoflagellate Alexandrium ostenfeldii (Dinophyceae) as the causative organism of spirolide shellfish toxins. Phycologia 2000, 39, 67-74.

48. Stirling, D.J. Survey of historical New Zealand shellfish samples for accumulation of gymnodimine. N. Z. J. Mar. Freshwater Res. 2001, 35, 851-857.

49. Biré, R.; Krys, S.; Frémy, J.M.; Dragacci, S.; Stirling, D.; Kharrat, R. First evidence on occurrence of gymnodimine in clams from Tunisia. J. Nat. Toxins 2002, 11, 269-275.

50. Pavela-Vrančić, M.; Ujević, I.; Ninčević Gladan, Ž.; Furey, A. Accumulation of diarrheic toxins in the mussel Mytilus galloprovincialis from the Adriatic Sea. Croat. Chem. Acta 2006, 79, 291-297.

51. Yasumoto, T.; Murata, M.; Oshima, Y.; Matsumoto, G.L.; Clardy, J. Seafood Toxins on American Chemical Society Symposium Series. In Diarrhetic Shellfish Poisoning; Ragelis, E.P., Ed.; American Chemical Society: Washington, DC, USA 1984; pp. 207-214.

52. Yasumoto, T.; Murata, M.; Oshima, Y.; Sano, M. Diarrhetic shellfish toxins. Tetrahedron 1985, 41, 1019-1025.

53. Marcaillou-Le Baut, C.; Lucas, D.; Le Dean, L. Toxic Dinoflagellates. In Dinophysis Acuminata Toxin: Status of Toxicity Bioassays in France; Anderson, D., White, A., Baden, D., Eds.; Elsevier: New York, NY, USA, 1985; pp. 485-488.

54. Mountfort, D.O.; Suzuki, T.; Truman, P. Protein phosphatase inhibition assay adapted for determination of total DSP in contaminated mussels. Toxicon 2001, 39, 383-390.

55. Üthermöhl, H. Zur Vervollkommnung der quantitativen Phytoplankton Methodik. Mitt. Int. Ver. Theor. Angew. Limnol. 1958, 9, 1-38.

Sample Availability: Not available.

(C) 2011 by the authors; licensee MDPI, Basel, Switzerland. This article is an open access article distributed under the terms and conditions of the Creative Commons Attribution license (http://creativecommons.org/licenses/by/3.0/). 